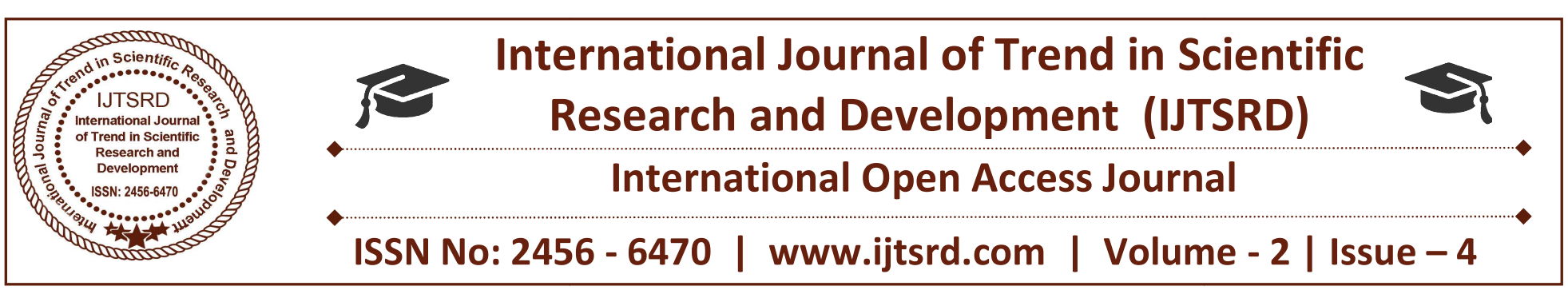

\title{
Evaluation of The Implementation of Integrated Business Training Models for Kawedegan Villagefarmers, Nganjuk-East Java Indonesia
}

\author{
Teodora Winda Mulia, Lodovicus Lasd, Lena Elitan \\ Faculty of Business, Widya Mandala Catholic University, Surabaya, Indonesia
}

\begin{abstract}
This research is motivated by the condition of the life of the farmer community of Perhutani farmers in Kawedegan Hamlet, Balonggebang Village, Gondang Sub district, Nganjuk Regency which beside the low level of education, also do not have permanent livelihood. Farmers of Perhutani farmers cultivate sweet potatoes and crops. Sweet potato is a healthy food for people with Diabetes Mellitus (DM). This study aims to find a model of integrated business skills training as an effort to empower farmers in developing entrepreneurship skills. The approach used in research is Research and Development.
\end{abstract}

Keywords: integrated training model, farmers, community empowerment

\section{INTRODUCTION}

The agricultural sector is a sector that has a strategic role in the structure of national economic development. This sector is a sector that does not get serious attention from the government in nation building. Starting from protection, credit to other policies is not one that is profitable for this sector. Agricultural development programs that are not directed to the goal even further plunge the sector to destruction. Yet this sector is a very large sector of labor and most of our people depend on it. The agricultural sector is the highest employment sector, at 44.5 percent in 2006 (BPS). Nevertheless, the contribution of the agricultural sector in Gross Domestic Product (GDP) is only 13.3 percent. Given the unequal contribution of GDP and the amount of labor absorbed, the level of labor productivity in the agricultural sector is the lowest. Compare that with the industrial sector which accounted for 28.9 percent of the national GDP but absorbed only 12.1 percent of workers. As a result, the welfare of households working in the agricultural sector will be lower than those employed in the industrial sector.

The actors who contribute considerable contribution to the national economy are 40 million workers among the 90 million workers across Indonesia. The majority of them are narrow with an average of 0.3 ha. They are only a cultivator of the farms that the urban people already possess. Without knowing well the characteristics and who they subsidize and support in the agricultural sector can not be enjoyed. Yet all the subsidies and support provided to lift their welfare. Law Number 32 Year 2004 regarding Regional Autonomy explains in the direction of regional development should always take advantage of various existing sources. In the general provisions of article 2, it states that the utilization of natural resources and other resources are carried out fairly and harmoniously. Relationships in the utilization of natural resources and other resources as regulated in article 17 include: (1) authority, responsibility, utilization, maintenance, impact control, cultivation, and conservation, (2) revenue sharing for the utilization of natural resources and other resources, and (3) environmental and spatial harmonization and land rehabilitation. Implementation of food crop subsector development as a result of utilization of resources in the framework of regional autonomy should be able to strengthen the position of farmers, other agribusiness actors and agricultural apparatus.

The potential of natural resources and the available environment is very possible to be developed, it's just because of the limited ability of the community in managing it then the potential can not be used maximally. Despite the policy on the right to manage forest resources independently to communities 
surrounding the forest, namely the issuance of a policy on HPHKM (Community Forest Concession Rights) through Minister of Forestry Decree No. $677 / 1998$, but the expenditure is considered to be relatively new, while the poverty of the surrounding community the forest has multiplied. For the people around the forest that do not belong to members of the cooperative, it is considered less attention. Thus, this policy on management rights has not been fully perceived by all layers and has not yet provided a sense of security to the community around the forest in the long run (Prasetijo, 2003).

The limited ability experienced by the community around the forest is the result of previously less empowered in community forest management (PHBM), thus causing poverty for farmers in forest villages. The inability of rural communities identical to poverty is always relevant to the level of education, health, and nutrition resulting in low productivity. According to statistical data (Kompas.com), 75 percent of Indonesian farmers' education level is not finished and graduated from elementary school, 24 percent graduated from junior and senior high schools, and only 1 percent graduated from college. In addition, in addition to the low level of education, the inability of the community is also caused by the impact of government policy on the development of agriculture in general and rural development that is less in favor of farmers and village communities. This situation causes the increase of pockets of poverty in almost all regions or provinces in Indonesia, including the province of East Java.

East Java Province is the largest province in Java Island and in Indonesia. Data from the Central Bureau of Statistics show that for three consecutive years from 2007 to 2009, East Java province was included in the five provinces with the poorest people in Java Island. BPS (2009) divides districts in Indonesia based on pockets of poverty into three categories, group one means districts with very poor families, group two means districts with family, and group three means districts with poor families. Nganjuk District which is part of East Java Province, including group two. Kawedegan Hamlet, Balonggebang Village, Gondang District, is one of the pockets of poverty in Nganjuk regency. The village is a small hamlet on the edge of the teak forest. The soil conditions are less fertile and contain lots of lime. Farms rely heavily on rain. If not, then irrigation for agriculture is done by buying water to the owners of drilled wells, it means that this can only be done by farmers who have enough capital. Agricultural crops developed here include rice, sweet potato, corn, lombok, onion, melon and palawija.

The villagers have a low level of education. In addition to cost, awareness of the importance of education is also still very less. Most of the people are illiterate, not just the parents, the younger generation are still illiterate. Even if there is a school, the highest only graduate Elementary School. People's economic lives are below the poverty line and generally work as farm laborers, firewood searchers and teak leaves in the forest. Only a small portion owns its own farmland, and that is only a small patch. While people who migrate to the city, working as factory workers and domestic workers. This condition is caused by poverty, low level of education, and the absence of special skills they have. From the various limitations of surrounding forest resources, as mentioned above, globalization in various aspects of social economy has in fact become a serious threat to the development effort and the improvement of the welfare of farmers community. Although also realized an opportunity if it can be realized a guidance to the community as through skills training in an integrated from various elements. Integrated skills training activities will be able to assist the community in finding livelihoods and entrepreneurship capabilities in accordance with the potential of the environment to increase the income or welfare of farmers. Previous studies that have investigated farmer-related training in community empowerment demonstrate the need for an integrated entrepreneurship-based entrepreneurship training model. Sukarta (2010) research on the influence of environment, entrepreneurship, and entrepreneurial motivation on entrepreneurial learning and business performance.

This research was conducted on the business of broiler breeder in Tabanan regency. The results showed that entrepreneurial learning and business growth are influenced directly and significantly by business motivation, entrepreneurial learning gives direct influence to business performance. Research Udayani (2010) about the relationship between the entrepreneurial spirit with the success of agribusiness (case in the broiler farming business in Bali). The results of this study indicate that there is a strong relationship between the entrepreneurial spirit with the ability of the application of agribusiness. Saputro (2009) examines the characteristics of dairy goat breeder entrepreneurs in Bogor district, West Java. The results show the most prominent characteristics 
of entrepreneur is the courage to take risks, independence, and leadership. Sudirman (2005) and Anwar (2004) who examined the effect of integrated business skills on community empowerment gave the result that the training was able to empower the community, increase family income, and reduce unemployment rate.

\section{Literature Review}

A. The Meaning, Purpose and Benefits of Training Many experts argue about the meaning, purpose and benefits of training. But from these various opinions in principle not much different. The Sikula in Sumantri (2000: 2) defines training as a short-term education process that uses systematic and organized ways and procedures. The trainees will learn knowledge and skills that are practical for a particular purpose. Moekijat (1993: 3) also states that "training is a part of education involving learning to acquire and improve skills beyond the prevailing educational system, in a relatively short period of time and with a method that prioritizes practice rather than theory". This statement is supported by Yoder (1962: 368) which defines training activities as an educational effort in a narrow sense, mainly done by instruction, practice, and discipline.

In this research study we will focus the meaning of training. Training contains more specific (specific) meaning and relates to the work / task that someone does. While the practical meaning is that the respondents who have been trained can be applied with the definition of training according to the Center for Development Management and Productivity is learning to change the behavior of people in carrying out their work. Training is basically a process of providing assistance to employees or workers to master special skills or help to remedy deficiencies in carrying out their work. Between education and training it is difficult to draw strict limits, as both general and training education is a process of learning activities that transfer knowledge and skills from sources to recipients. However, the differences between the two will be seen from the objectives to be achieved through the activity.

Public education (formal) according to Halim and Ali (1993: 3) is always related to the subject in concept and theoretical nature and is the development of one's personal attitude and philosophy. When training focuses more on activities designed to improve performance in performing tasks, education is more focused on developing knowledge and understanding of the overall environment. In another section he explained that training is more related to the specificity of teaching, the fact that views are limited to skills that are motor and mechanistic. The real difference with education, it is known that education in general is philosophical, theoretical, general, and has a relatively long time span compared to a training. While the meaning of learning, contains the meaning of an inherent learning process of a person. Learning occurs because of the people who learn and the resources available to learn. In the sense of learning is the condition of a person or group that performs the learning process.

In an organization, institution or company, training is regarded as a therapy that solves problems, especially with regard to improving the performance and productivity of an organization, institution or company. Training is said to be a therapy, because through training activities the employees are expected to increase their knowledge and skills so as to give a high contribution to organizational productivity. With the increased knowledge and skills as a result of training, employees will be more mature in the face of all changes and developments facing the organization. Thus, training activities are more focused on improving the knowledge, skills / skills (skills), experience, and attitudes of trainees on how to carry out certain activities or occupations. This is in line with the opinion of Simamora (1995: 287) which explains that training is a series of activities designed to enhance the skills, knowledge, experience or change of attitude of an individual or group in carrying out a particular task.

In community development, training is given as an effort to improve the ability of citizens in dealing with the demands and changes in the environment. Provision of training for the community aims to empower, so that citizens become empowered and can participate actively in the process of change. Training can help people or communities to apply their knowledge and skills. Training can also lead to changes in the habits of community work, changes in attitudes toward work, and in the information and knowledge they apply in their daily work.

Training activities can occur if a person or a community realizes the need to develop the potential and ability to meet the needs and satisfaction of life, therefore empowerment activities are needed. Empowerment can be interpreted as an effort to 
release poverty through economic growth and backwardness through education. Empowerment activities undertaken through training aims to strengthen a person's position through the growth of the individual's awareness and capability, identify problems encountered and think of steps to overcome them. The essence of empowerment activities is the motivation to understand the conditions of everyday work situations as well as foster their ability and courage to be critical of the conditions they face, so the key is to build participation.

Moekijat (1993), put forward "the term training demonstrates a process of enhancing the attitudes, abilities and abilities of workers to perform special jobs". This expression indicates that training activities are a process of helping participants learn to gain effectiveness in doing their work both now and in the future through the development of habits of thoughts and actions, skills, knowledge, and attitudes. Training activities are also conducted in an effort to solve various problems encountered in daily work activities and anticipate the possibility of problems that occur in the future. This is in line with Soenanto's view in Moekijat (1993: 4) that training is a learning activity to change people's plans for doing work. The implementation of good and optimal training will improve the ability of trainees to overcome the problems faced in carrying out tasks and can improve productivity and quality of work. Taking into account this understanding, it turns out that the purpose of training is not only to improve knowledge, skills and attitude alone, but also to develop one's talent, so that it can perform the job as required. Moekijat (1993: 2) describes the general objectives of the training as follows: (1) to develop skills so that work can be completed more quickly and more effectively, (2) to develop knowledge, so that work can be solved rationally, and (3) develop attitudes, resulting in a willingness to cooperate with friends of employees and with management (leadership).

Thus training is intended in a broader sense, and is not limited solely to developing skills and guidance only. Training is provided in the hope that community members can do their job well. People who have followed the good moon also from the community who did not attend the training. In addition to the above meanings and objectives mentioned above the training also has a number of benefits, as Siagian (1985: 183-185) puts forward 10 benefits that employees or employees can derive from the following training activities:
$>$ Helping employees make better decisions,

$>$ Improving the ability of the workers to solve various problems faced,

$>$ The interaction and operationalization of motivational factors,

$>$ The incidence of encouragement in workers to continue to improve their work ability,

$>$ Increased ability of employees to overcome; strees, frustrations, and conflicts that in turn enlarge self-confidence

$>$ Availability of information on various programs that can be utilized by employees in the framework of technical and intellectual growth.

$>$ Increase job satisfaction

$>$ The greater the recognition of one's ability

> The greater the willingness of workers to be more independent

Reduce the fear of facing new tasks in the future.

While for community groups the training activities provided can provide several benefits, including (Amiharja dan Hikmat (2001):

$>$ Helping the community to accelerate the fulfilment of needs as an effort to improve tarap life

Improving attitudes to be able to adapt to environmental changes and to make decisions well and correctly.

Increase motivation to learn, and always be willing to develop knowledge and ability

$>$ Growing confidence and high solidarity among peoples.

\section{B. Training Approach}

Friedman and Yarbrough (1985) in the book "Training strategies" revealed that: in the course of training can be traced from the dimensions of the steps, the trainers and the method. The training process is generally done through two approaches, namely; The receptive approach used as a diagnostic phase or more known as the "bottom-up" approach, and the directive approach used as an instructional phase or called a "top-down" approach. Both approaches have the same importance with its function, and used to complement each other. Two things to consider in balancing the two approaches in a training, namely by knowing the situation of using each approach and know how to implement it.

In the first stage of each training task is a situation diagnosis by trying to respond to statements about the status quo, the difference between a person's behavior and the expected behavior of the trainee, realistic 
training objectives, and the method used to achieve a structural objective. The next stage is the implementation by using the directive approach, in which case the Training Program is manifested in practice. Receptive and directive sequences are a cycle and can be repeated in a training program. Community as a trainee is classified as an adult, therefore the principle principles applied in the training process should refer to the principle of adult learning. In adult learning (andragogy) Knowles (1980: 41) explains about the concept of andragogy with "the art and science of learning adults learn", the art and science in helping adults learn.

The implementation of this training is more focused on using participatory approaches, although there are some descriptions that have similarities with other approaches. With a participatory approach, other approaches will also be easier to adapt, because with a participatory approach the community as trainees will not feel offended or coerced when ordered and will be happy to accept (Wahyono, 2013). This approach will be more effective because as previously revealed that the main target is the adult community who generally have a lot of experience. In addition, through participatory approaches, the community as trainees will play a larger and more extensive role, from the identification of needs, planning, implementation and to assessing the outcomes of training activities. In particular this approach is used to involve trainees in order to participate actively in the training process and in running the business.

Adaptation of some of the approaches Friedman and Yarbrough discloses in participatory approaches such as receptive (bottom-up) approaches emphasizes community participation in exploring sources or potentials in terms of existing and potential human and natural resources, a top-down approach is an activity or participation of the community in utilizing human resources or SDA as proof of its participation in the successful implementation of the training program provided by the organizers as well as in the form of policies issued by the government. The use of this participatory approach can be done directly and indirectly. Directly is usually done in small groups or with face to face, and this will feel more effective because there will be a relationship of intimacy among the participants. Indirectly usually done in a larger group that is not possible for each participant to meet face to face (Sudjana, 1992: 266). Thus in this training the implementation of the approach is approached with a participatory approach that is done directly, because the number of participants is relatively small.

\section{Training Models}

The conduct of training is generally used more by government or private agencies or organizations, as well as corporations, using different models. The modeled training modes, all of which aim to improve the quality of human resources as a workforce, which ultimately can increase production. Implementation of the training can also be conducted in the community, which also aims to improve the quality of community members such as knowledge or specific skill areas.

Training specialists usually conduct training using individual steps or cycles based on the model they develop. Among the existing training models the experts develop them vary, some illustrate only through simple cycles, and some are described in detail. Nevertheless from several models developed found the steps or stages that have similarities, as in the implementation of general training. The similarity begins with identification, with the aim of finding and assessing the needs to be trained, and ending with the evaluation. From the existing training models, it can be seen as revealed by Nadler (1982: 12), known as The Critical Events model (CEM) or called an open model whose steps look more detailed and specific. In this model not all variables can be identified or determined at the time of designing the training program, but at every step always in the evaluation and in return. The training cycle on CEM can be described as follows:

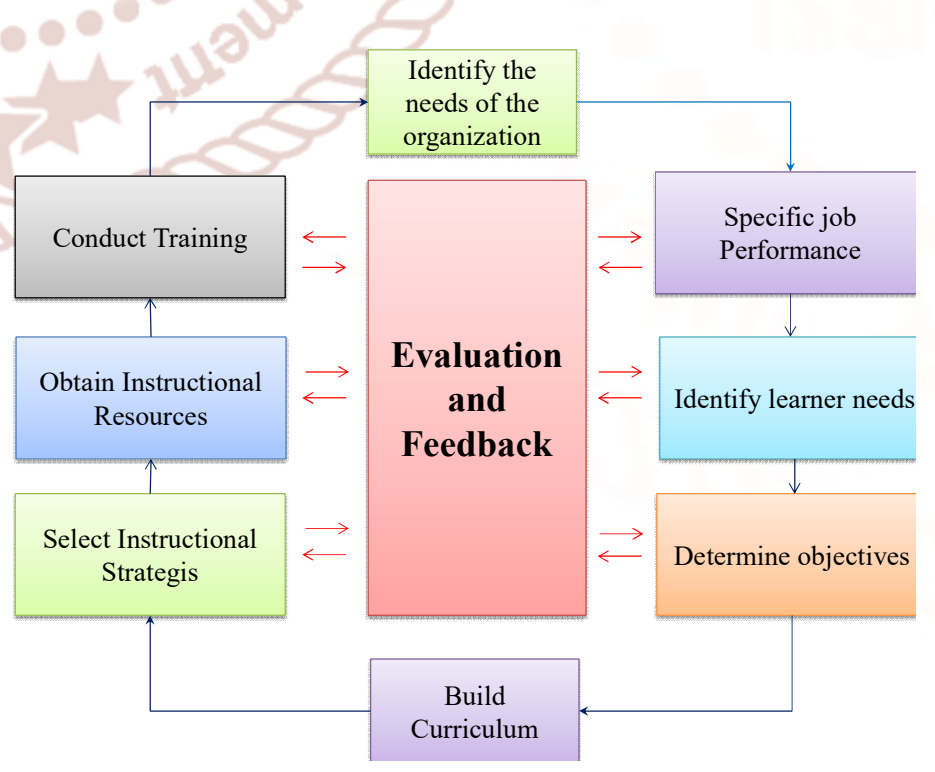

Figure1 : Model Critical Event Sumber : Nadler (1982:12) 
The model developed by Nedler starts from: 1) determining the needs of the organization, 2) determining the specification of tasks, 3) determining the needs of the learner, 4) formulating the goals, 5) determining the curriculum, 6) choosing the learning strategy, 7) obtaining learning resources, and 8) carry out the training, and then back again to determine the needs. This rotation aims to see the advantages and weakness of the training that has been implemented, whether it still needs to be repaired or indeed is in accordance with the desired goals by the organization.

Mayo \& Du Bois (1987: 3) developed a training model through five phases, known as the Continuous Loop Training Development and Implementation Model or the Closed-loop Continuous System. The five phases are: 1) phase of operational requirement, 2) defining training requirement phase, 3) developing objectives phase, 4) planning, developing, and validating training phase; 5) phase of conduct and evaluate the training. Schematically these five phases can be seen in Figure 2.3 below:

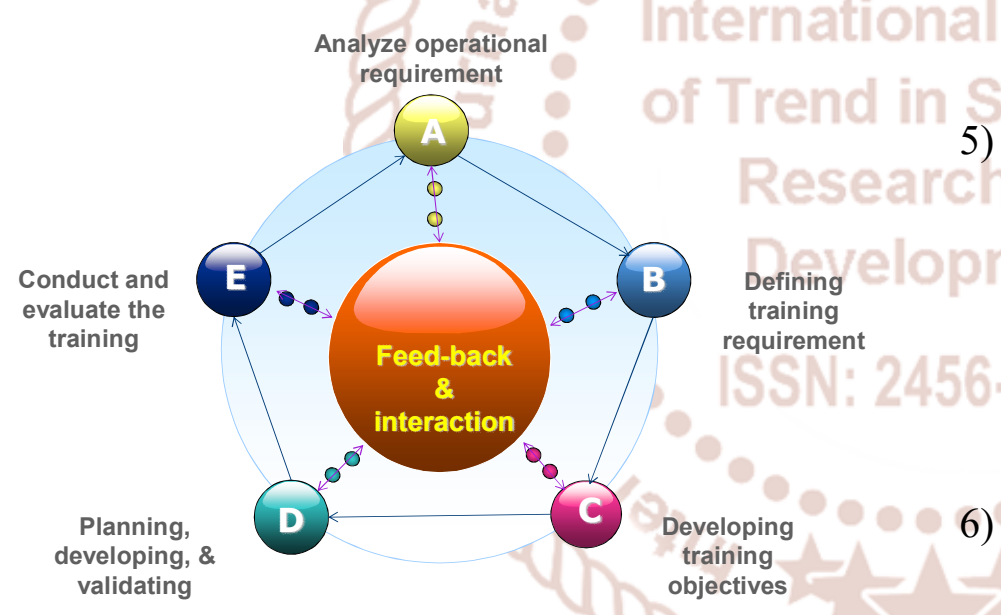

Figure2 :Five Stages Training Cycle Sumber : Mayo \& Du Bois, (1987:32)

Friedman and Yarbrough (1985: 4), put forward six stages of the training process (six stages of the training process). The six stages used in the training process are as follows:

1) The first stage, aware of the need (awareness of need). The gap between the present state and the expected state is usually due to two attributes inherent in the human function, iechange and inspiration. Change is a "boost" and aspiration is a "pull" that raises the need for training. Changes create problems that must be solved immediately, whereas aspirations tend toward a growth stage for added value.
2) The second stage, analyze the problem (analyzing the problems). If the need is felt to be general, then it needs to be analyzed as closely as possible, so the formula is not too general or not too specific. If analyzing each question then it should be done by answering the questions first: what is the difference between present and expected performance? Are these perfomans useful to overcome differences? And Does it improve skill?

3) The third stage, determine the options (knowing options). When preparing choices, it is necessary to include an explanation of the objectives of its advantages and disadvantages, andexperiences that can help trainees develop guidelines to determine the best options.

4) The fourth stage, realizing an adoption asolution. In dealing with a solution first is to provide an explanation of the procedure so that it becomes clear and understandable to those who will determine the procedure. And hereinafter is the provision of support whereby the procedure must be run about its advantages and disadvantages. In this case the role of training is to narrow the choices of trainees who channel the trainees' efforts on specific ways or channels.

5) The fifth stage, teaching a skill (teaching a skill). If training is expected to influence the trainee's thinking, attitude or knowledge, then the role of training is to assist the participants in learning a skill. Then provide feedback on the work of trainees according to the steps taken up to the assessment of the results of work / learning outcomes.

6) The sixth stage, integration in the system (integration in the system). If in the learning procedure the trainee does not generate the effect of cooperation in the learning situation, then in the follow up it is necessary to assist the trainees to perform such cooperation procedure in a system that requires cooperation, for example in "team work". This integration is indispensable because in the final stages of training there are always problems facing trainers in integrating their new learning outcomes into their work context. Another type of "system integration" is to focus on developing a better "team" interaction within an integrated workgroup.

The six stages in the training process can be seen in Figure 2.4. the following: 


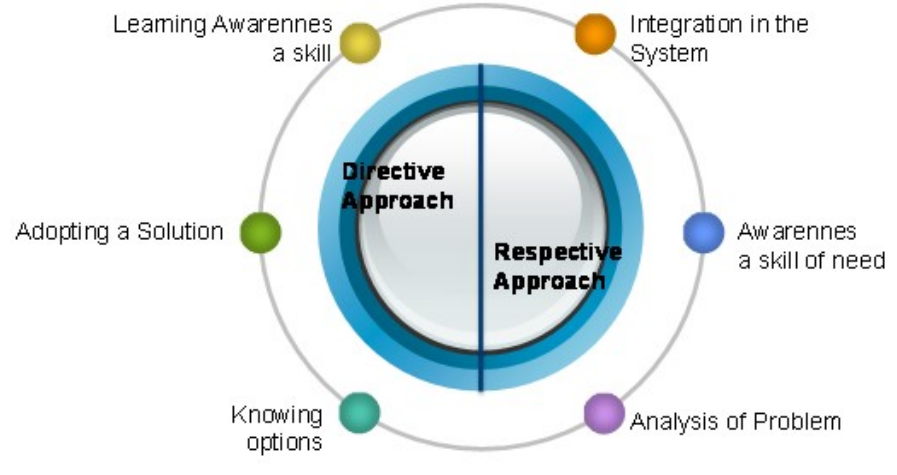

Gambar 3 . Six Stages of the Training Process

Sumber : Friedman \& Yarbrough (1985:4)

Generally the model of training system in its cycle is divided into three stages namely; planning stage, implementation stage and evaluation phase. Of the three cycles, in the average implementation of each model always begins with the needs analysis, and then drafted the training design followed by the development of training materials, organizing training and ending with evaluation. The activity or execution of such models can be said as a standard step in every training exercise. The difference between one training and other training is more on the side of the learning approach and the organizing of the training, but in principle it all has the same goal of increasing the knowledge, skills and attitudes of the trainees.

As a process, training is not a complete program and can be made instantaneously. It takes time, and includes the intensity, frequency, and duration of time, and is continous and involves various elements that must be managed properly (Moeljani, dkk 2017). The system approach requires systematic and resultsoriented training management. Each component has a relationship with other components, so the more perfect each process is done, the better the results obtained.From the models described and described, as well as in relation to this research topic, researchers did not adapt one model in full, but collaborated on several models deemed to be compatible with the type and target group of research.

As in modeling it is more likely to model the training developed by Nadler (1982: 12), the reason for adapting this model because every step is always evaluated to provide feedback. While in the steps will be more simplified and more similar as revealed Goad (1982: 11). For the Friedman and Yarbrough model (1985: 4), seeing the existence of awareness of needs as a first step to solving the problems faced, and emphasizing the importance of teamwork or in an integrated way. Integration in the form of teams or working groups is felt more effective, especially in an effort to apply the learning outcomes of participants into their work.

\section{E. Concept of Integrated Business Skills Training} Integrated business skills training is a series of activities designed to equip knowledge, skills and change of attitude both for individuals and groups with several types of skills, to be used as a source of effort in order to meet the needs of life. Business skills training is an integrated learning process that moves from a theme as a center of attention, which is used to understand the symptoms of other concepts, both on the concept of the type of skill being studied as well as the concept of other types of skills. As a concept, integrated business skills training can be said to be an approach in teaching and learning by involving several material studies on skills aimed at providing meaningful experiences to the learning community. It is said to mean because in an integrated business skills training, people learn to understand the concepts they learn and practice through direct experience and connect them with other concepts they have previously understood.

This training or learning skill as revealed (Gilkey 1985: 195) is a process whereby a person's environment is deliberately managed to enable him to participate in certain behaviors and special conditions or generate responses to specific situations. The environmental management process that makes a formation and followed the adjustment of existing elements to achieve the purpose of this training is called integration. The process of integration is a progressive development in realizing the perfect conformity between several elements secaraberama or mutual support to create a perfect culture (totalculture). For example: Linton (1984: 267) pointed out the change in the life of the Tanala tribe in Madagascar as a result of the inclusion of the paddy technology system, which eventually the community became involved in moderate switches before they knew only the cultivation of paddy fields.

From the knowledge and experience gained by the community directly as a result of the learning process can be said as a learning process in the form of diffusion. The learning process in diffusion form includes the following steps: 1) the assignment. or the inclusion of new cultural elements to the target group, 
(2) acceptance of the new element by society, and (3) the integration of these accepted elements into existing cultures (Linton 1984: 258). Integrated business skills training which in its learning is more practice-oriented or practical application, has a tendency that suits the needs of the learning community.

Especially in the integrated business skills training that emphasizes the involvement of learners in learning, it will make the people learn actively involved in the learning process and in decision making. The involvement of citizens learns in every process of learning activities in accordance with the expression Knowles (1980), that participants learn primarily for adults, the learning process must be implemented by involving the active participation of the studying citizens. This kind of approach will make a meaningful experience for the participants or the learning community itself. As stated by John Dewey with the concept of "Learning by doing it" which in one of the content of learning prioritizes areas of skills that are felt useful in life and can be directly felt by the community.

Integrated business skills training can be viewed as an effort to improve the quality or life, especially in order to offset the social impacts of policies that narrow the field of employment for the community. Basically integrated business skills training is a training system that enables citizens to learn, both individually and in groups, to actively seek, explore and discover scientific concepts and principles holistically, meaningfully and authentically. Active means that integrated business skills training is basically developed in addition to basing on the inquiry discovery approach, also taking into account the desires, interests, and abilities of the learning community. Residents of learning need to be actively involved in the training process from planning, implementation, to evaluation.

Holistic means a phenomenon or event that is the center of attention in integrated business skills training observed and studied from various fields of science at once, not from a fragmented point of view. Integrated business skills training enables citizens to learn to understand a phenomenon from all sides. So that in the end will make citizens learn more wisely and wisely in addressing or facing various events. Meaningful means the study of a phenomenon from various aspects as described above, allowing the formation of a kind of inter-schematic interwoven of the learned citizens.

A concise reference of all concepts acquired, and their association with other concepts will add to the significance of the concept being studied. The interrelationships between these concepts will result in more functional learning activities, so that learners are able to apply the learning outcomes to solve real problems in their lives. Authentic means integrated business skills training also allows citizens to learn to understand directly the concepts and principles to be learned, because in the process of teaching and learning they do activities directly. Citizens learn to understand from their own learning outcomes, the results of the interaction of facts and events, not just the results of notices from tutors. Information and knowledge acquired are more authentic. Tutors are more of a facilitator and a catalyst, while the learning community acts as an information seeker and knowledge seeker. Tutor provides guidance where the direction is passed and provide facilities as optimal as possible for the achievement of the goal. Thus, integrated business skills training is not merely designing the activities of each of the related areas of study. Activity activities may be undertaken, but they may not be compatible with the philosophical, psychological and juridical grounds of integrated business skills training. Integrated business skills training can be developed from a mutually agreed theme by glancing at the material aspects of the curriculum that can be learned through the development of the theme.

Needs analysis of skills training model After knowing the condition of farmer community of land tenure of Perhutani and agricultural environment in Kawedegan village, the next step is empowerment to farmer community through training. Training activities are needed because of the current ability of farmers, especially to find and run undeveloped businesses. Skills possessed only in farming types of vegetables and have not been able to switch to other types of commodities. After the skills of farming vegetables that serve as a source of community business is prohibited, now the community of land tenants Perhutani more not utilized.

Based on the exploration results, it is also found that the training model that has been implemented by various government agencies or social institutions has not been able to touch the whole society. As experienced by the community Kawedegan, Village 
Balonggebang, District Gondang, Nganjuk regency, who have never received another training. Can we understand together if the problem of community empowerment, especially related to poverty becomes very complex, because it is not enough to be handled by only one agency or institution. Therefore, cooperation from various parties such as government institutions, private sector, community leaders, and the farmers themselves, especially individuals or community groups that are targeted by the training program are needed. The existence of training programs as community empowerment, especially those aimed at improving income is very important. Training program or through skill learning given, is one form of action that can empower the community in overcoming the problems being faced. This statement is one reason for consideration of the need for involvement from various parties in the implementation of training programs.

From the analysis of skills training needs for the farmers in Perhutani land in Kawedegan, Balonggebang Village, Gondang Subdistrict, Nganjuk Regency, will then present a model of integrated skill training as an effort to transfer commodities. Through integrated business skills training, T farmers communities will have the opportunity to develop their skills so that they can serve as a new source of business. In addition to the support of existing resources, also the types of skills developed still have broad market opportunities (Teguh, 2004). The intended direction in planning and implementing integrated business skills training is to encourage and create a situation that allows for the community to flourish. Growing opportunity given aims to improve knowledge of skills and attitudes of the community in running the business, which is from start processing, maintaining, harvesting and marketing the results.

Development of Integrated Skills Business Training Model: Preparation of conceptual model Linton (1984) reveals; the development model in learning and training consists of three models: 1). The procedural model, which is also called a descriptive model, displays the steps to be followed in producing a product. 2) Conceptual model, that is model that is analysis to component of product that will be developed and also relation between component. 3) Theoretical model, which is a model showing the relationship of change between events.

In this integrated business skill training model use the learning development model that follows the conceptual model, that is by doing description analysis on the components used as the component of the learning model. The conceptual model design is the framework or basics of a model build that would be structured into a more operational model for testing. On the one hand, the implementation of the test is in the form of integrated business skills training program for horticultural farmers as an effort to transfer commodities in Kawedegan, Balonggebang Village, Gondang Sub-district, Nganjuk Regency. On the other hand, it is useful to obtain academic findings for the development of scholastic education outside school.

The village community of Kawedegan as the target group of trials, as a farmer of Perhutani farmers only received training once, which is training to make fried brambang organized by the Agriculture Training Center (BLKP) Nganjuk, precisely in 2014. This activity has only touched a small number of women, housewives, while for heads of households as vegetable farmers have never received any kind of assistance. Until finally they are forbidden to work on land with these commodities.

The integrated business skills training that is designed consists of four types of skills is an effort to answer the problems, and as an effort to meet the needs of the community. The four types are packaged into a training program whose outcome is to be a joint venture or group. Each type of skill is usually trained separately, but it is carried out in a training package in this research. This activity is intended, in addition to seeing the interconnection of each type of skill, also aims to meet the needs of farmers from the start that felt very urgent or in the short, medium and long term. Thus continuously the results of the training will be enjoyed, and horticultural farmers who currently have no permanent livelihood will soon get their jobs back.

In the implementation of integrated business skills training in addition to required good management, also need to be supported by various factors such as; ability of faculty, appropriate curriculum, resources (nature, human, and organization / culture), facilities / infrastructure, market opportunity, and source of cost (capital). The success of the integrated business skills training model is not only for the enhanced ability of the participants and to have new business, but through the involvement of the participants in each activity in the training can help the participants to; (1) assessing self-attitude and behavior, (2) solving problems faced, 
and (3) being able to feel what others are feeling. (Jhigan, 1999). The design of training models developed and trained to the farming community includes several issues; First, the description of the training model illustrates the concepts, objectives, features of integrated business skills training, operating models and which are different from other models especially as PLS units. Second, describe the objective conditions of society

Kawedegan and potential resources available to support the implementation of training. Third, in the effort to find the usefulness of the developed training model, it is necessary to select the type of skill that suits the needs of the community as a learning citizen. In this case found four types of skills, namely the cultivation of onions, raising chickens, making crackers onion and buying and selling activities. Fourth, the design of programs and learning materials and the steps taken in training, such as; processes, learning methods in training, learning climate, and others developed with regard to the target group. Fifth, the learning process in training illustrates how to process inputs and instrumental inputs in training to produce mutually agreed outputs.

The roles and tasks of facilitators, target groups, and technical resource persons are developed into training activities (Sumodiningrat, 1997). The organizing of participants and learning materials, the use of methods in learning and training and coaching, are all described as being integrated. Sixth, monitoring and assessment of results from learning and training, conducted to see progress of the target group as learners in mastering the knowledge, skills, and attitudes that have been learned. From the design of the model described, the next step the researchers set up a conceptual model. In preparing the conceptual model, it will still pay attention to some of the things covered in the model design. Broadly speaking, the conceptual model of integrated business skill training that is developed follows a three-step model:

1. Planning, in addition to planning the learning resources, curriculum, materials, training facilities and infrastructure, prior to the implementation of the training also need to be considered preparation of learning, such as:

a) what objectives are to be achieved from the implementation of the training after the conditions and problems faced by the community, b) determine the subject according to the type of skills to be developed, c) determine the training target group consisting of a number of participants in accordance with the requirements, d) formulate training objectives in accordance with the General Instructional Objectives and Specific to be achieved.

2. Implementation, in the stage of implementation and observation, which also need to be considered in accordance with the plan, are: a) conducting preliminary test, ie by giving a number of questions through a written sheet and through observation, b) development of lesson material and practice, this activity is done after obtaining preliminary results and after knowing the results of the trials conducted in the first stage. This activity aims to improve the initial conceptual model, especially if deemed deficient, c) Development of learning strategy is a strategy to determine the steps of delivery of materials according to the type of business to be developed.

3. Evaluation, evaluation phase is done according to the design and preparation of the established model. Evaluation activities aim to know how the process and outcome of the training activities that have been implemented. Evaluation is done through written test and through observation activities.

\section{FINDINGS AND DISCUSSIONS}

In general, this study has been in accordance with the expected goal of developing a model of training that is able to empower the community farmers Perhutani land in commodity switch. This model was developed based on the consideration that the peasant community actually still has the potential to move forward and develop as long as given opportunities and opportunities. Based on the problems and objectives presented in this study, then associated with the findings of research and discussion, then in general can be made some conclusions as follows:

1. The condition of the farming community in Kawedegan village

From the results of identification of the condition of the community of farmers in the village of Sand PasirAngling village Suntenjaya, researchers found:

a. The inability of the farmer community to run the business by switchingcommodities are caused more by low levels of knowledge and income.Such conditions, making the farming community difficult to meet the needsfamily economy. Especially after the introduction of a ban on processing the land of Perhutaniwith horticultural crops, which increasingly makes the farmers into deprivation andhelpless. The income level of farmers who earn this kind of income 
is felt by the communityvery far from enough and make the life of the peasant community deeperdifficulties and continue to enter into the cycle of poverty. The reason for the issuance of the banfarmers, because the land they have been working on is a protected forest orwater catchment areas that when cultivated or hoeed in addition will reduce the water sourcemuch needed by society will also cause erosion.

b. The low level of community education is mostly influenced by low income sources. The average level of community education in the village of Kawedegan only finished primary school or dropped out junior high school. In addition to the educational facilities that are far from where people live, road conditions as a liaison is also very difficult to travel by vehicle or just more comfortable on foot. With these conditions make the farming community becomes difficult to be able to improve the ability in an effort to meet economic needs, without the help of others.

c. The large number of unemployed farmers is due to the fact that in addition to not owning their own farmland, it also has not been able to develop into other types of businesses. Giving education, especially through training will be able to provide new knowledge and skills to serve as livelihoods, which ultimately can increase the income of farmers and reduce poverty. This statement is reasonable, because in principle local governments still allow the community to work on or cultivate the land, with a note they must be willing to change the type of commodity or from the type of seasonal crops into long-term crops such as; banana. In addition to farming they are also allowed to breed such as: cattle, sheep, chickens, and others, only it must be adapted to existing environmental conditions.

d. The absence of institutions or related agencies that conduct guidance to the community, especially to perform other activities after the enactment of the ban. The coaching they received previously only from individuals or owners of venture capital as well as buyers of the products they are running. The role of the community of farmers themselves is more just as a farm laborer, although there are some who provide capital by means of profit sharing. After the imposition of a ban on farming types of vegetables, the owners of capital not want to speculate to replace with other types of commodities. Such a situation is very difficult for farmers, because in addition to the very limited ability, also hit on the problem of cost or business capital.
2. Findings of integrated business skills training model

From the exploration results in Kawedegan in an effort to empower the community to develop the business capability, the appropriate step is through the provision of skills training. The developed skills training model is directed to the development of productive enterprises that are adapted to the environmental conditions and are carried out in an integrated manner. Based on the findings of experimental results, the conceptual model of the training developed can be

summed up as follows

\section{a. Conceptualization of training model}

First: Departing cultural values gotong royong that exist in the community, was able to provide a strong inspiration in underlying framework conceptual model of integrated business skills training. This framework starts from identifying problems and needs, as well as the potential local resources needed from planning to evaluating the program. Steps of the activities prepared in the implementation of this program are; (1) from planning to evaluation of training programs conducted jointly by farmers' communities with facilitators, (2) design of training models and programs developed tailored to the learning needs and agreed upon by potential participants and involving various parties such as related institutions / agencies, community leaders and farmers themselves.

Second: The trainees assume that the conceptual model and the type of skills developed are appropriate to their needs. This model results from joint planning and agreement by involving facilitators and relevant agencies such as Local Government, Agriculture Agency, Perhutani, BRI and local community leaders. Third: The conceptual model of skill training developed consists of two stages: 1) The trial is limited or the first stage, which aims to see how far the initial ability of the trainee. In the limited trial focused on aspects of the development of training models such as, in the management of community training, farmers expect in addition to the presence of outside companions as well as from the local community. To facilitate accountability in doing the work, the group is divided into two. PBM is done in tutorial, more practice, not bound to the schedule and its evaluation involves participants. The pilot study in addition to technical and non-technical testing on the type of skills to be developed, also discusses the use of learning materials or modules such as discussing 
content, form, sentence, grammar and participants' understanding. This activity is done by involving the participants directly and accompanied by learning resources / facilitators. 2) The second phase trial, which aims to further strengthen again from the results of previous trials are considered still lacking. Thus the farmers' communities become more empowered in developing their ability to switch commodities.

In the second stage of testing the same as before, which is divided into three main steps and some descriptions, such as;

a) Training planning, such as (1) preparation of faculty, (2) curriculum preparation, (3) preparation of schedule and activity material, (4) preparation of facilitator of learning process. In planning, it is also necessary to prepare the steps to be undertaken in the learning process, such as (1) determining the training objectives, (2) determining the subjects, (3) determining the target group of prospective participants, (4) formulating the objectives / success rate,

b) Implementation of the training, such as: (1) implementation of preliminary tests, (2) development of lesson materials and practice, (3) development of learning strategies, c) Implementation of training evaluations, such as: conducting written tests assisted with observation and development tools program revision based on results.

c). Validation and implementation of conceptual models

Validation: The integrated business skills training model offered aims to empower the community of farmers in the effort to transfer the commodities. To obtain a conformity confidence of the model design that is tailored to the needs of the trainees, validation of the model to various parties or experts. Thus the resulting conceptual model will be adequate as a training model. Implementation: Based on the results of implementation or pilot conducted, integrated business skills training model has been deemed appropriate to empower the community. In the execution and assessment results of the models piloted in the first and second stages, significantly able to make a positive contribution in the life of the studying citizens. The contribution has been in accordance with the needs of the learning community or the trainees in order to improve and improve their skills such as: in terms of knowledge, skills and attitudes, as well as aspirations to make changes in living conditions as expected.

\section{Effectiveness of integrated business skills training model}

The effectiveness of the training model developed in developing business capability is assessed based on the extent of the participants' empowerment after following the training process. The results of the training were analyzed qualitatively and quantitatively. The findings of the qualitative analysis result, it can be said that after completion of the training the participants can be empowered in the working group to develop the ability in trying with new commodity types. In addition, after completion of the training the participants can identify the resources to be developed. Understanding participants on the basic concepts in the business is also good. So as long as descriptive instructional goals have been achieved. The results of qualitative analysis is reinforced by the results of quantitative analysis. Quantitatively the test is done by comparing the pretest results with the post-test results in the three aspects tested, ie aspects of knowledge, skills and attitudes. From the results of these tests, showed significant results, meaning that there is a change or increase the ability of participants after treatment. Quantitative analyzing is done by comparing two groups of research subjects paired before and after. The results are known that there has been a marked difference between the participants before and after the training. Thus it can be said that integrated business skills training is effective to empower the learning community in trying with new commodity types. In addition, the results of the analysis also indicate that integrated business skills training activities bring a real impact in changing the perceptions and attitudes of citizens learn in running the business.

\section{REFERENCE}

1) Adimihardja,K. dan H. Hikmat. 2001. Participatory Research Appraisal: Pengabdian danPemberdayaan Masyarakat. Humaniora Utama Press, Bandung.

2) Anwar.(2004). Pengembangan Model Pengelolaan Pembelajaran Keterampilan Berbasis

SosialBudaya bagi Perempuan Nelayan.(Studi Perubahan Sosial Melalui Introduksi Teknologi padaKeluarga Nelayan Suku Bajo di Kabupaten Kendari). Disertasi. UPI Bandung.

3) Ellitan, L., Mulia, TW., Lasdi, L. 2018. Integrated Training Model of Business skill for Kawedegn Farmer, Nganjuk, East Java, International Journal 
International Journal of Trend in Scientific Research and Development (IJTSRD) ISSN: 2456-6470

of Trends In Scientific Research and Development, Vol. 2 Issue, Jan-Feb. pp. 563-571.

4) Fiedman, P.G and Yarbrough, E.A. 1985. Training Strategis From Start to Finish. PrenticeHall.,Englewood Cliffs, Nes Jersey.

5) Gilkey, R. et al. (1985). Definisi Teknologi Pendidikan. Diterjemahkan oleh Yusufhadi Miarso dkk. Jakarta: Rajawali.

6) Goad, T. W.(1982). Delivering Effective Training. San Diego. California, Inc.: University Associates.

7) Halim, A., dan M. M. Ali. 1993. Training and Profesional

Development.[Online]:http:/www.fao.org/docrep/ W5830E/w5830e0h.htm. (12 Juni 2004).

8) Jhingan, M. L. 1999. Ekonomi Pembangunan dan Perencanaan. Rajawali Pers: Jakarta.

9) Knowles, M.S. (1986). The Adult Learner A Neglected Species. Third Edition. Houston: GulfPublishing Company.

10)Linton, R. (1984). The Study of Man (Antropology Suatau Penyeldikan Manusia). Diterjemahkanoleh Firmansyah. Bandung: Jemmars.

11) Mayo, $P$ and Du Bois, PH. (1987). The Complete Book of Training. California University, CSU.

12) Moekijat. 1993. Evaluasi Pelatihan dalam rangka Peningkatan Produktivitas. Bandung: Mandar Maju.

13) Muljani, N., Ellitan, L., Koesworo, Y., (2017), The Role of Microfinancial Institutions from The Member's Perspective, IJournals: International Journal of Social Relevance \& Concern, vol. 5 (8), August. p. 52-60

14) Nadler, L. (1982). Designing Training Programs: The Critical Events Model, London: AddisonWesley Publishing Company.

15) Prasetijo, A. 2003.Akses Peran Serta Komuniti Lokal dan Pengeloaan Sumber Daya Alam dalamAkses perta Masyarakat. Penerbit ICD: Jakarta.

16) Saputro, Dani Sudibyo. 2009. Analisis Karakteristik Wirausaha Peternak Kambing Perah diKabupaten Bogor Jawa Barat. Skripsi. Fakultas Ekonomi Manajemen Institut Pertanian Bogor.
17) Siagian, S. P. 1998. Manajemen Sumber Daya Manusia. Jakarta: Bumi Aksara.

18) Simamora,H. 1995. Manajemen Sumberdaya Manusia. Jakarta.

19) Sudirman.2005. Model Pelatihan Keterampilan Usaha Terpadu Bagi Petani Sebagai Upaya AlihKomoditas".(Studi Terhadap Petani Penggarap Lahan Perhutani di Desa SuntenjayaKecamatan Lembang Kabupaten Bandung). Disertasi. UPI Bandung.

20) Sudjana, H.D. 1996. Pendidikan Luar Sekolah, Wawasan Sejarah Perkembangan Falsafah \& TeoriPendukung Azas. Bandung: Nusantara Press.

21) Sukarta. 2010. Pengaruh lingkungan, sifat kewirausahaan, dan motivasi wirausaha terhadappembelajaran wirausaha serta kinerja usaha. Tesis. Unud: Denpasar

22) Sumantri, S. 2000. Pelatihan dan Pengembangan Sumber Daya Manusia. Fakultas Psikologi Unpad: Bandung.

23) Sumodiningrat, G. 1997. Pembangunan Daerah dan U Pemberdayaan Masyarakat. PT. Bina RenaPariwara, Jakarta.

24) Teguh, A. S. 2004. Kemitraan dan Model-model Pemberdayaan. Penerbit Gaya Media, Yogyakarta.Tjiptono, F. dan Diana, A. 1998. Total Quality Management. Yogyakarta: Andi offset.

25) Udayani, R. 2010. Hubungan Antara Jiwa Kewirausahaan dengan Keberhasilan Usaha Agribisnis(Kasus pada Usaha Peternakan Ayam Ras Pedaging di Bali). Tesis. Unud: Denpasar.

26) Undang-Undang Republik Indonesia Nomor 19 Tahun 2004. Tentang Kehutanan. Bandung:Fokusmedia.

27) Undang-Undang Republik Indonesia Nomor 41 Tahun 1999. Tentang Kehutanan. Jakarta: PT. Mitra Info.

28) Wahyono, B., (2013). Permasalahan di dalam Lembaga Keuangan Mikro (LKM).http://www.pendidikanekonomi.com/2013/ 07/permasalahan-di-dalam-lembaga-keuan gan.html

29) Yoder, D. (1962). Personal Principles and Policies, Printice Hall Inc, Maruzen Company Ltd, Second Edition. 